\title{
Assessing the Socioecological Perspectives of Eucalyptus Cultivation and Plantation Expansion in Laos
}

\author{
Xayphanya Chanthalath ${ }^{*}$, Liu Yong ${ }^{1}$, Mukete Beckline ${ }^{1}$, Southdavone Inthilath ${ }^{2}$ \\ ${ }^{1}$ School of Forestry, Beijing Forestry University, Beijing, China \\ ${ }^{2}$ School of Environmental Sciences and Engineering, Beijing Forestry University, Beijing, China \\ Email: *chanthalathmail@yahoo.com, lyong@bjfu.edu.cn, munasawa@gmail.com, boumpoum@yahoo.com
}

How to cite this paper: Chanthalath, $\mathrm{X}$., Yong, L., Beckline, M. and Inthilath, S. (2017) Assessing the Socioecological Perspectives of Eucalyptus Cultivation and Plantation Expansion in Laos. Open Access Library Journal, 4: e4243.

https://doi.org/10.4236/oalib.1104243

Received: December 11, 2017

Accepted: December 25, 2017

Published: December 28, 2017

Copyright $\odot 2017$ by authors and Open Access Library Inc.

This work is licensed under the Creative Commons Attribution International License (CC BY 4.0).

http://creativecommons.org/licenses/by/4.0/

\section{c) (i) Open Access}

\begin{abstract}
In Laos, the cultivation of fast growing trees as eucalypts has been promoted due to a rapid decline in natural forest cover. However, this expansion of fast growing trees might not end in a win-win situation for both humans and the environment. This paper examines the social and ecological potentials of Eucalyptus (Eucalyptus spp.) cultivation and the resultant environmental consequences. To achieve this, we carried out a comprehensive survey of published scientific literature obtained through Web of Science, Researchgate, Mendeley, and Google Scholar. We found that eucalyptus is a fast-growing source of wood and produces oils used in fuels, fragrances, and insecticides. Despite being of this high commercial value to rural farmers and large industries, eucalyptus harms watersheds and if not properly managed, destroys ecosystems through its allelopathic and water absorption tendencies. Nevertheless, with adequate and effective management and proper sustainable planning or involvement of rural farmers in the decision making process, eucalyptus cultivation would have a very positive social and ecological impact.
\end{abstract}

\section{Subject Areas}

Agricultural Science, Biodiversity, Conservation Biology, Ecology, Ecosystem Science, Environmental Sciences

\section{Keywords}

Eucalyptus Cultivation, Forest Cover Loss, Laos Shifting Cultivation, Plantation Expansion 


\section{Introduction}

\subsection{Background}

In many tropical countries such as Laos, rural communities live inside or around forested landscapes on which their livelihoods depend. For these rural communities, the forests serve as sources of wood, fuelwood for cooking and heating [1]-[3]. Local populations also depend on these forests for farmland, medicinal plants and hunting grounds. Additionally, several forest resources and their products are also used for sociocultural and recreational purposes [4]-[6]. Besides serving as source of timber, fuel and fodder for forest dwellers, forests also play an important role in regulating the global climate [7]-[9].

As a result of this reliance, forests are continuously under threat giving rise to constituent biodiversity loss, associated forest loss and degradation [10]. Globally, forests have suffered unprecedented destruction due to unsustainable exploitation and management of in-situ resources [3] [7]. According to [11], about 2.3 million square kilometers of forest were lost during the period 2000 to 2012 and 0.8 million square kilometers of new forest were gained. Their study also revealed that about 0.8 million square kilometers of new forest were gained during this 12 year study period. The tropics were observed to have experienced the greatest losses and gains (through regrowth and plantation), with losses outstripping gains [11].

Globally, tree cover loss was observed to have attained a record 2.97 million square kilometers in 2016 [12]. The loss is $51 \%$ higher than the previous year with forest fires being the primary cause of this spike. For example, in the Brazilian Amazonian region tree cover loss was estimated at over $370,000 \mathrm{~km}^{2}$ nearly three times more than in 2015. This increase mainly occurred in the states of Pará and Maranhão, which were heavily affected by fire in late 2015 and early 2016. Despite these fire events, deforestation due to agriculture, logging, and mining still remains the major driver of annual global tree cover loss [12].

In many tropical countries including Laos, tackling the multiple challenges related to forest degradation and loss enormously contributes towards sustainable forest management. That notwithstanding, the implications for strategic and practical planning must be carefully done in order to achieve these sustainable forest management goals. From this perspective and within the past two decades, forest loss and degradation have preoccupied researchers, policy makers and development organizations [3]. This stems from the observable depletion of forest as a result of the combined effects of agricultural expansion, wood extraction, population distribution, and density [13]. Therefore, identifying the drivers of this associated forest depletion, curbing measures and consequences of these measures would help reduce negative impacts on resources, while ensuring forest sustainability (Figure 1).

\subsection{Situational Analysis}

In Laos, over $80 \%$ of the population lives in rural areas with subsistence agriculture 


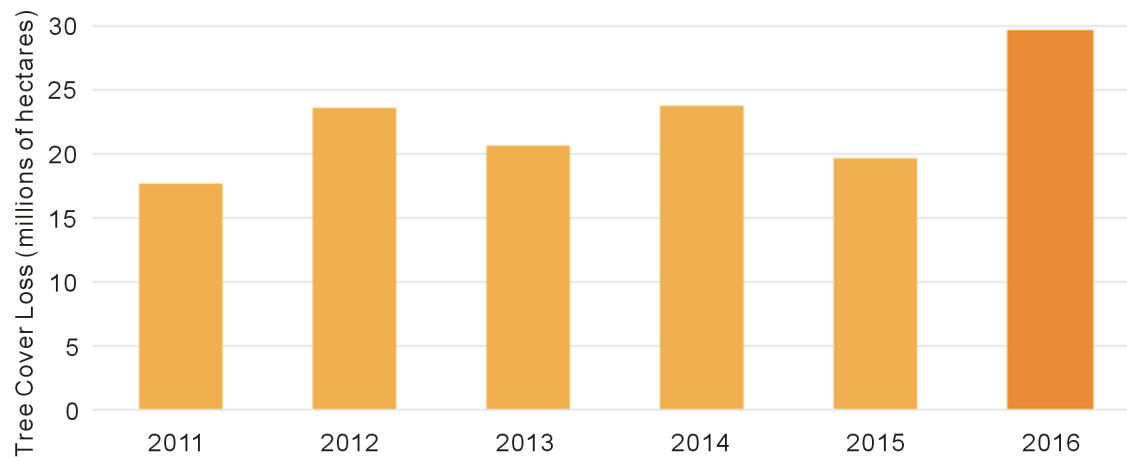

Figure 1. Global trend in tree cover loss for 2011-2016. Sourced from Weisse and Goldman, (2017).

http://blog.globalforestwatch.org/data/global-tree-cover-loss-rose-51-percent-in-2016.html

and forest resource harvesting as their major sources of livelihood [14]-[16]. Therefore, within the past three decades, forest resources in Laos have come under increased pressure and degradation. For instance between 1990 and 2005, Laos lost over $6.8 \%$ of its forest cover or around $11,720 \mathrm{~km}^{2}$, due to increased commercial logging activities [17]. According to the results of the last reconnaissance survey of forest cover in 2002, the total land area of Lao PDR covered by natural forest (canopy density of higher than $20 \%$ and height of above $5 \mathrm{~m}$ ) was $98,247 \mathrm{~km}^{2}$ or around $41.5 \%$ of the total land area, while the drylands (lowland dry dipterocarp forest) covered approximately $13,172 \mathrm{~km}^{2}$ or $13.9 \%$ of the total land area. Majority of this land area is located in the central and southern parts of the country [14]. It is estimated that more than $300 \mathrm{~km}^{2}$ of forest land are annually logged, with an annual log harvest of some $425,000 \mathrm{~m}^{3}$ contributing to over USD 164.2 million to the economy in 2011, which is approximately $2.1 \%$ of the national GDP [13] [18]. Consequently, after hydroelectricity, the sale of timber has become the second largest source of national foreign currency earnings.

Another major reason for this rapid decline in forests is the impact from the bombing campaign inflicted on Laos during the Vietnam War (1964-1973). This caused not only significant direct damage to forest and land, but also the displacement of many communities, leading to the disruption of traditional land use systems and resulting in many land use conflicts between communities [13] [14] [19] (Figure 2).

\subsection{Relevance of the Study}

This study may serve as a basis for effective collaboration between the rural populations, national forestry stakeholders and policy makers to design effective community-based forest management and rural development programs aimed at reducing deforestation, forest degradation and the negative impacts associated with eucalyptus cultivation. Therefore the knowledge obtained from this study, may serve as an input into conservation policy especially in the planning, development and management of eucalyptus cultivation. This will specifically provide 


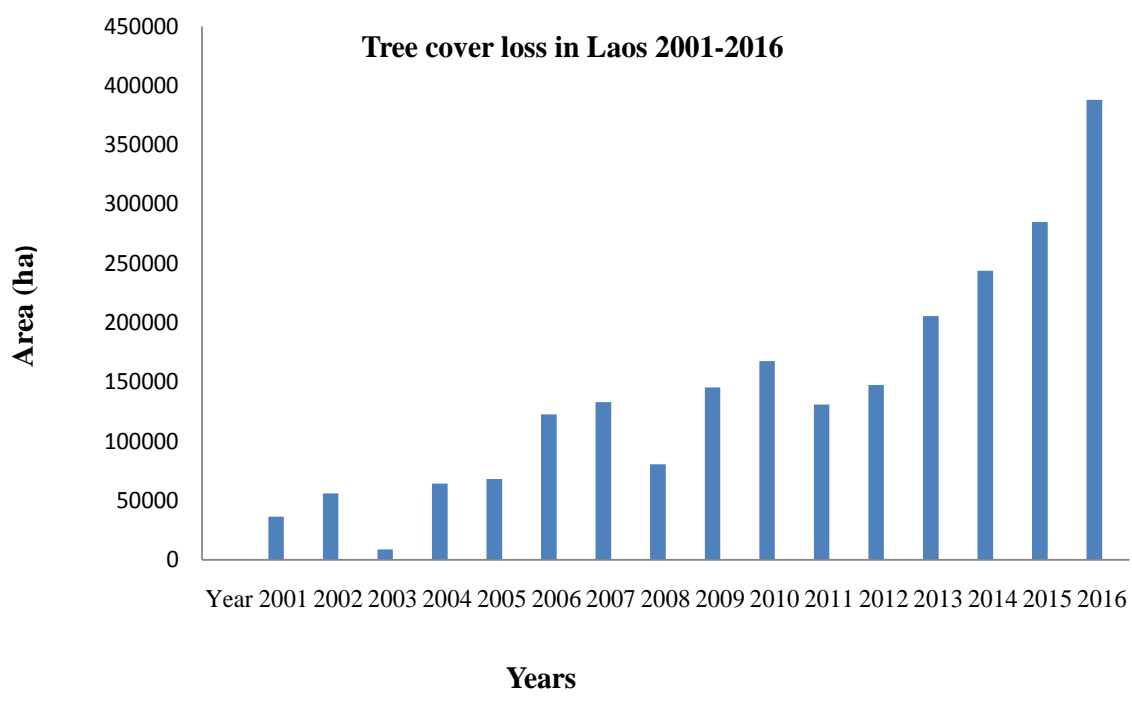

Figure 2. Tree cover and loss with $>30 \%$ canopy density in Laos for the period 2001-2016. Adapted from Hansen et al. (2013). http://www.globalforestwatch.org/country/LAO

policy-making basis for the government while also contributing to forest conservation, through monitoring and evaluation activities.

\subsection{Methodology of the Study}

Such as to obtain a more up-to-date overview of the state of world forests including the state of eucalyptus cultivation in Laos, we conducted a general search of online scientific literature in Google.

Scholar and university catalogues. We used the keywords Laos, forest loss, eucalyptus plantations, forest management, forest conservation, silviculture, forest monitoring, and evaluation. Laos is our country of interest while forest loss is the main driver behind the expansion of tree plantations. Meanwhile, eucalyptus plantations are forest management, forest conservation, silviculture, forest monitoring, and evaluation initiatives aimed at curtailing this forest loss in Laos. Scientific and other online media publications for over 25 years were selected for assessment. To make our search more comprehensive, we also examined other search engines such as Web of Science, Mendeley, and Researchgate databases and searched for similar documents.

The over 1000 publications obtained were then narrowed down to deforestation, forest degradation, reforestation, afforestation, and forest plantations. Here, we only examined documents relevant to our research on deforestation, forest degradation, reforestation, afforestation, and forest plantations around the globe with particular emphasis on Laos. A bulk of these documents covered various other topics which were unrelated to any of our selected categories. For instance, we discarded publications involving research on socioeconomic issues, biodiversity and sustainability or which had empty links to forest plantations around the globe. Of the over 1000 publications, only about 50 publications had directly investigated forest plantations around the globe as related to Laos. The bulk of 
these studies were mostly conducted in Europe, the Americas, Indonesia, China, and with very limited from Africa and the small Island states.

We then used this information to present a detailed analysis of deforestation, forest degradation, reforestation, afforestation, and forest plantations around the globe with particular emphasis on Laos. In addition, we examined the relevance of eucalyptus cultivation especially the ecological perspectives associated with its cultivation. The paper is divided into two sections with the first looking at global forest plantation cover. Here, we explore the global context paying particular attention to Laos and eucalyptus cultivation. In the second section, we look at the ecological perspectives of eucalyptus cultivation (Figure 3 ).

\section{Biophysical and Tree Cover Dynamics in Laos}

\subsection{Biophysical Perspectives of Laos}

Laos is a landlocked country in Southeast Asia $\left(17^{\circ} 58^{\prime} \mathrm{N} 102^{\circ} 36^{\prime} \mathrm{E}\right)$, thickly forested with rugged mountains and an estimated population of about 6,803,699 inhabitants [15] [20]. The Mekong River forms a large part of the western boundary with Thailand, whereas the mountains of the Annamite Range make-up most of the eastern border with Vietnam while the Luang Prabang Range forms the northwestern border with the Thai highlands. There are two plateaus, the Xiangkhoang in the north and the Bolaven Plateau in the south. The climate is tropical and influenced by the monsoon pattern [16] [20]. There is a distinct rainy season from May to November, followed by a dry season from December to April. The capital and largest city Vientiane and other major cities include Luang Prabang, Savannakhet, and Pakse [20] (Figure 4).

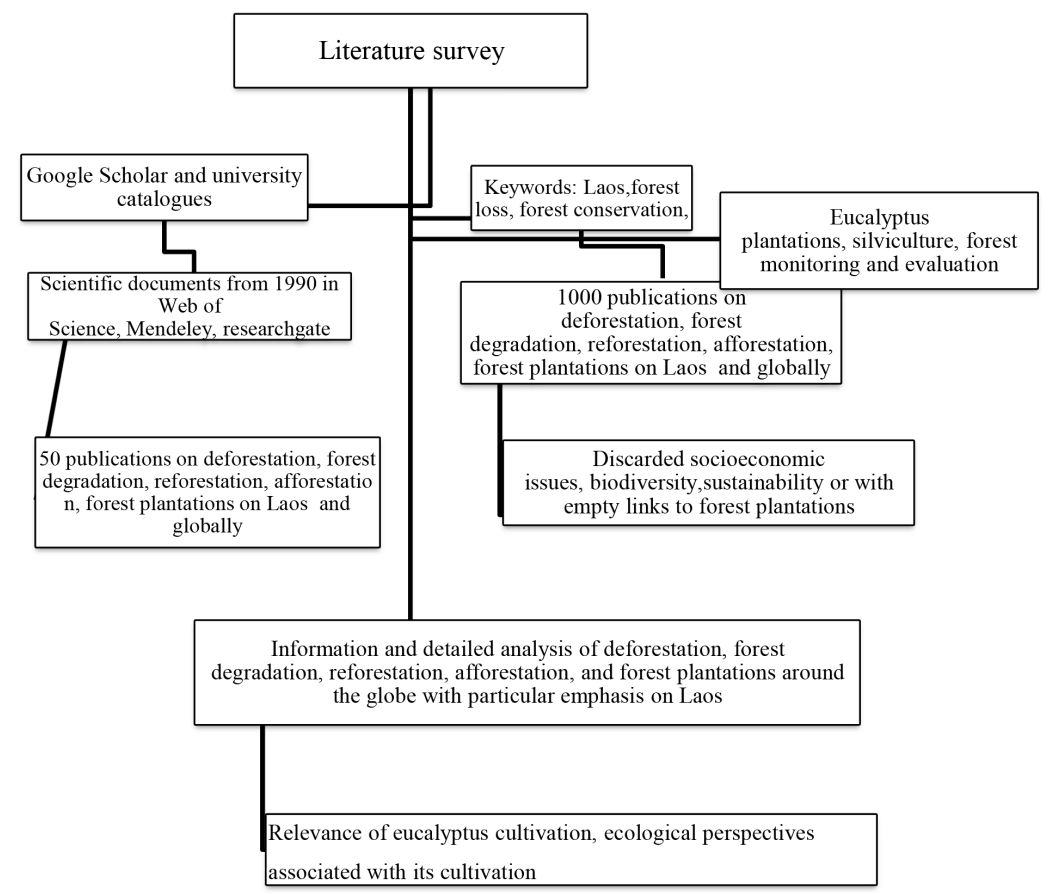

Figure 3. Flow chart reflecting the literature selection procedure. 


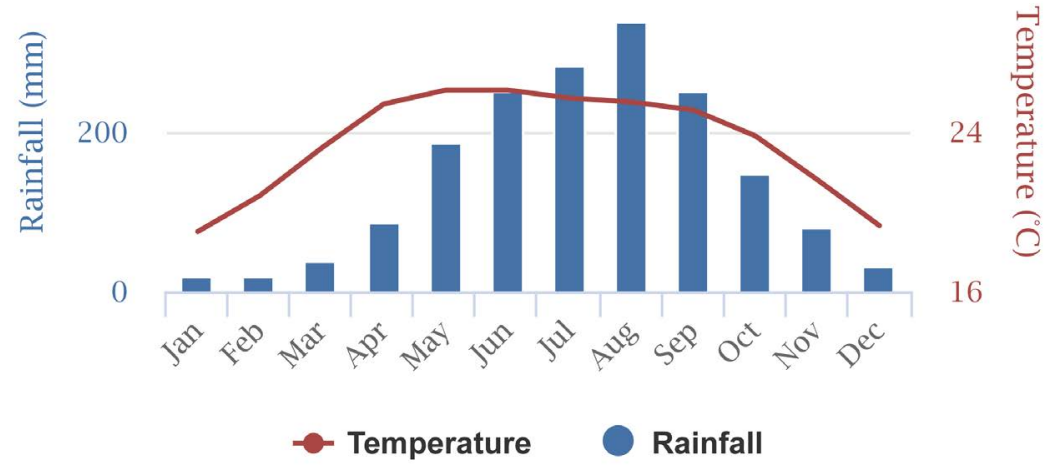

Figure 4. Average Monthly Temperature and Rainfall for Lao, People's Democratic Republic of from 1901-2015. Sourced from the World Bank (2017). Data produced by the Climatic Research Unit (CRU) of University of East Anglia (UEA).

http://sdwebx.worldbank.org/climateportal/index.cfm?page=country_historical_cli $\underline{\text { mate } \& \text { ThisCCode }=\mathrm{LAO}}$

It is important to evaluate how climate has varied and changed in the past. The monthly mean historical rainfall and temperature data can be mapped to show the baseline climate and seasonality by month, for specific years, and for rainfall and temperature. The chart above shows mean historical monthly temperature and rainfall for Lao, People's Democratic Republic for the period 1901-2015.

The level of education in Laos is low and illiteracy is relatively widespread due partly to the lingering problems after the Civil War, 1954-1973, which greatly affected the educational sector. In addition, poor infrastructure in mountainous areas makes it difficult for many children to go to school while most children serve as farm helps to their families [21] [22]. Laos is considered one of the most bombed countries in the world throughout the history. Around one third of all the bombs dropped during the war did not explode and it is still a major problem for the local communities who practice agricultural. Agricultural activities with bombs in the ground make it risky and difficult for the rural people. This is further compounded by the low utilization of the agricultural land and its inability to provide the increasing population with enough food [14] [22] [23].

Laos is rich in timber, hydropower and minerals such as iron ore, copper, coal and gold. Until the beginning of the $20^{\text {th }}$ century, the extraction of most natural resources was limited, but since then, the Lao government has entered into several agreements with foreign companies for exploitation. As a result, the mining industry has grown substantially as well as the forestry and hydropower sectors. The most important exports are wood products (legal wood), coffee, electricity, tin, copper, gold, clothes and other textiles. Most of the exports are going to China, Vietnam and Thailand [14] [21].

\subsection{Perspectives of Tree Planting in Laos}

Over the past three decades, the increase in demand for wood and associated 
forest products and efforts to mitigate greenhouse gas emission has galvanized the surge in the development of tree planting (reforestation, afforestation) initiatives around the globe [24]. Short-rotation or fast growing trees particularly eucalyptus (Eucalyptus spp.), Acacia (Acacia spp.), Teak (Tectona grandis), and rubber (Hevea brasiliensis) have been targeted as sources of raw material for bioenergy, paper and pulp industries and carbon sequestration [24] [25].

The global extent of forest plantations has been observed to be on a steady increase by an average of $2 \%$ annually. Over 1.4 million $\mathrm{km}^{2}$ of forest plantations have been planted globally and about 1.1 million $\mathrm{km}^{2}$ have been established primarily for wood production. The proportion of the world's industrial wood sourced from forest plantations is expected to continue to increase, to nearly $50 \%$ by 2040 so as to meet the demand for wood products by the growing human population [21].

In Laos for instance and within the past three decades, due to a growing population and the shortage of lowland areas, have led to more intense slash and burn cultivation in upland and highland areas. This has led to shorter fallow periods, soil degradation and increased pressure on forests [13] [19] [22]. To address this forest decline, the government of Laos has set an ambitious target to increase forest cover up to $70 \%$ by 2020 through afforestation, reforestation and stabilization of shifting cultivation [19]. The area under plantation cultivation increased from a mere $10 \mathrm{~km}^{2}$ in 1990 to over $2000 \mathrm{~km}^{2}$ in 2009 especially eucalyptus and rubber plantations. Most especially due to its rapid growth rate and short rotation period, the cultivation of various Eucalyptus species is being promoted throughout the country [19] [26]. Furthermore, the plant species are important for being sources of wood where, mature trees have a range of commercial uses, including timber for construction and furniture manufacturing [21] [26].

Eucalyptus is a diverse genus of flowering trees and shrubs in the Myrtaceae with majority of the species and subspecies originating from Australia and its close islands [27] [28]. Including its purebred, variation and natural hybrids, there are over 945 species such as Eucalyptus globulus, Eucalyptus camaldulensis, Eucalyptus occidentalis, Eucalyptus urophylla, Eucalyptus grandis etc. [29]. The tree species is globally cultivated including in the Americas, Europe, Africa, the Mediterranean Basin, the Middle East, China, and the Indian subcontinent. Eucalyptus produces oils that are used in fuels, fragrances, insect repellence and antimicrobial products [30] [31].

In Laos, eucalyptus plantations were introduced through the Lao-Australian Reforestation Project in the early 1970s. Initially, the plantations were developed to identify the best species, provenances and establishment methods. The main species planted were Eucalyptus tereticornis and Eucalyptus camaldulensis [26]. In 1980s, Burapha (Swedish-Lao joint venture Company), and other companies began increasing commercial tree plantation activities. By 2016 Burapha and Stora Enso, (a Finnish forestry giant) had already established more than $200 \mathrm{~km}^{2}$ 
of eucalypt plantations across the country [22]. Also, this upsurge in eucalyptus plantations stems from the lack of experience and knowledge for promoting fast growing trees by local rural communities. This because villagers still keep their traditional life style with community forest and dependence on natural resources (Figure 5).

\section{Socioeconomic and Ecological Perspectives of Eucalyptus Cultivation in Laos}

\subsection{Socioeconomic perspectives}

According to [13] [21], eucalyptus is widely accessible and important to the rural poor, it is ecologically sustainable and incentives aimed at their utilization, add their value and income earnings. Additionally, eucalyptus directly and indirectly contributes to livelihood security by providing a variety of consumable and profitable income and livelihood resources [22] [32]. Therefore, eucalyptus cultivation by rural communities often complements a multitude of other livelihood activities to ensure household needs are met year round without which millions of people in Africa, Asia and South America would be unable to survive. Hence, sustaining eucalyptus tree forests and livelihood activities they support is crucial for social resilience [13] [21] [26].

Several studies have documented the importance of eucalyptus among rural households, especially in Asia [13] [19] [21] [22] [26] [32]. These studies show that eucalyptus cultivation and utilization are essential livelihood activities for many rural Asians [32]. Since, eucalyptus resources and products are utilized both in the household or traded, eucalyptus harvesting is thought to result in less ecological damage than timber extraction. This is because eucalyptus usually regenerates quickly and most often their removal does not alter fundamental biophysical conditions and processes (e.g., carbon sequestration). In a related study, [21] found the Taungya system in Laos-an age-old agroforestry practice involving intercropping of crops with trees on the same unit of land as a win-win strategy to meet the needs of wood products and food at the same time.

\section{Tree plantations in Laos}

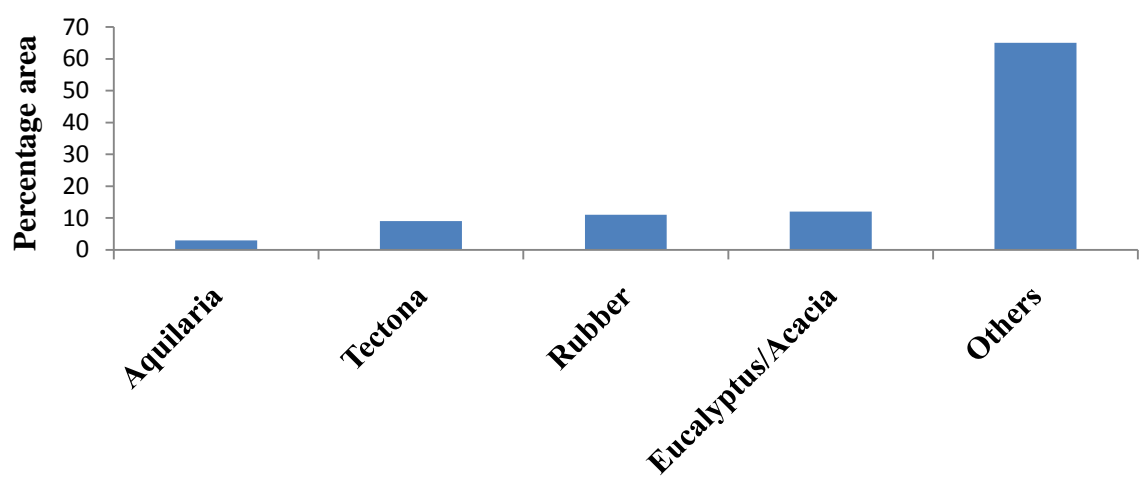

Figure 5. Distribution of species in forest plantations in Laos 2012. Sourced from Edberg, 2015. 
Similarly, [33] observed that because eucalypt performs well with a slender clean bole, farmers commonly grow eucalypt along land boundaries and sometimes use it as living fence posts. Also, [34] conducted a financial analysis of farm forestry in Northern Laos and found that farmers can earn a high economic return from planting trees such as rubber and eucalyptus. According to [35] despite the negative impact, benefit areas include possibility of greater income and welfare for farmers, attracting public and private sector services, encouraging rural people to enter the marketplace and diversify their income, and finding alternative sources of income to degraded forests.

While local traditional cultivation methods assisted by fertilizers and pesticides still persist, commercial plantation management models have been developed and tested. For instance, the Stora Enso's responsibility and agroforestry models in Laos have been developed to improve on the problem of eucalyptus plantation cultivation. The responsibility model ensures that before planting any trees, all unexploded bombs are cleared from the plantation area particularly along the Ho Chi Minh Trail (an area in Laos with a long history of warfare and hardship, where local communities are still suffering from the after effects of the Vietnam War) [22]. Meanwhile, the agroforestry model is based on wide spacing, where rice can be grown between the trees during the first two years, and other more shade-tolerant crops can be grown during the rest of the seven-year rotation period. The resulting rice yields are better than those obtained through traditional shifting cultivation methods, due to the use of improved agricultural practices and higher quality seeds [21] [22].

On the other hand, [36] argues that the adoption of plantation policy will cause displacement and impoverishment in Laos. Local villagers will be forced to abandon their traditional agricultural practices and move into permanent and commercial farming. Similarly [37] and [38] studied the implications of industrial forest plantation development in central and southern Laos and pointed out that plantation forestry leads to new ecological and social issues, such as the transformation of the primary forest to plantations and conversion of degraded forest on which local villagers depend for their subsistence. Another qualitative study by [39] argue that several programmes and policies related to internal resettlement, such as the Land and Forest Allocation Programs policy and other land reform policies, will accelerate the poverty of rural Laos and cultural distortion.

The government of Laos is yet to elaborate on a plan that will ensure that local communities benefit from the transition to plantation adoption and resettlement schemes. From an economic perspective, the necessary incentives and policy instruments needed to encourage the combination of out-grower schemes and concessional plantations and to more effectively integrate timber plantations with traditional agricultural livelihoods are missing [40]. This has led to mistrust of the government by rural farmers as the long-term and sustainable supply of materials is not guaranteed. Also, concrete and adequate assistance plans towards 
harvesting of mature trees, organization of and access to better national and international markets are absent. The government is yet to elaborate on the promotion of processing and final market products as well as subsidies or financial schemes to support farmers [40].

\subsection{Ecological Perspectives}

According to [41], a well-designed integrated eucalypt tree farm can deliver a range of environmental and on-farm benefits such as a decrease in ground water level (less risk of flooding) and waterlogging all year round. Therefore, well-designed plantings can reduce and manage the water table, decrease risk of soil salinization, improve soil fertility and thus drain swamps thereby reducing the risk of malaria [32] [42] [43]. In addition, just as natural forests, eucalyptus trees serve as windbreaks, reduce soil erosion; provide biodiversity, and on-farm aesthetic benefits. From another perspective, eucalyptus tree plantings are an effective strategy in offsetting the growing emissions of carbon dioxide and other greenhouses gases to the atmosphere.

Eucalyptus is an efficient biomass producer; it can produce more biomass than many other tree species. It also consumes less water per unit biomass produced than many other species of trees; but as a result of its fast growth and high biomass production eucalyptus species consume more water than other, less productive species [44]. Therefore growing eucalyptus in low rainfall areas may cause adverse environmental impacts due to competition for water with other species and an increased incidence of allelopathy. Allelopathy is a biological phenomenon by which an organism produces one or more biochemicals that influence the germination, growth, survival, and reproduction of other organisms [45].

The effects of eucalypt on run off, and therefore on erosion, vary greatly according to local conditions of climate, slope, and use of the ground vegetation and litter by local peoples. Also, lateral spreading and depth of penetration of the root systems of the eucalypts vary with species, and this has to do with the intensity of water uptake. Withdrawing of soil moisture also depends on stand density and soil and environmental conditions. In alpine dry sclerophyll conditions, soil water regime does not differ between eucalypt forests, grassland and herb fields [32] [44]. Meanwhile, in areas of deeper soils and higher rainfall regimes, soil water deficit created by eucalypt forests seems to be in the region of $250 \mathrm{~mm} / \mathrm{yr}$. In comparison with crop or pasture land, this means that eucalypt forested lands would yield approximately $70 \mathrm{~mm}$ per year less stream flow or ground water recharge. Also, transpiration rates differ among eucalypt species, varying between 20 litres per tree per day to about 40 litres per tree per day. Similarly, some eucalypt species have not developed mechanisms for controlling higher rates of transpiration and are likely to suffer from drought stress, which limits their range of habitats. Nonetheless, majority of eucalypt species, however, do have some control of the rate of transpiration, which helps them survive drought 
stress during part of every year, and as related to rainfall regimes of their natural habitats [44].

Studies in Central India and in the foothill zone of the Himalayas indicate that, in regions where large areas of Eucalyptus tereticornis plantations have been raised, the level of water in wells falls until the plantations are about 6 - 8 years in age, the culmination of mean annual increment (MAI) and thereafter reverts to the earlier levels [44]. In regularly harvested eucalyptus plantations, a major portion of the stored nutrients in the above ground biomass is removed. In firewood-scarce regions, except for the roots below ground level, nothing else is left behind. This system provides for nutrient loss which will occur in any tree species, as in agriculture. Meanwhile in the case of short rotations, this nutrient is often compensated through fertilizer applications. The biodiversity of a natural forest and that of a eucalyptus plantation are not comparable. The natural ecosystems are very diverse, whilst the biodiversity of eucalyptus plantations is limited.

\subsection{Management Perspectives}

In Laos, eucalyptus cultivation and management is thought to vary as a function of land and labour availability, size and income level of the household and investment capital of the company. The management process is thus basically oriented towards the production of maximum biomass, adopting short rotations and intensive management practices, which may result in adverse environmental effects such as soil compaction, soil erosion, nutrient export, pollution and other adverse effects due to the use of fertilizers, weedicides and pesticides, and fire hazards [13] [19] [21] [22] [26] [32].

In rural areas, farmers use manual weeding between rows of eucalyptus as a traditional method of management. No chemical or mechanical methods are used and weeding is usually conducted when undergrowth has become dense. Weeding is mostly done thrice a year, twice during the rainy season and once during the dry season. This is often during the first three years of planting and as a closed canopy is obtained, weeding is reduced to twice a year. In addition, farmers carry-out no thinning and pruning and therefore, a large dimension and high value timber is difficult to obtain within the shortest possible time. This is furthermore handicapped by the narrow spacing implemented during planting [46] [47].

Similarly, fencing-off stray animals is another major ecological problem because these animals disturb and destroy saplings, seedlings and young plants. Wooden fences are commonly used by farmers and other growers who cannot afford the extra costs of erecting barbed wires around their plantations. The use of fertilizers and herbicides is not common among rural planters due to the high costs, low household income and the belief that the soil is fertile enough to support tree growth.

In a related study, the Taungya system in Laos-an age-old agro forestry 
practice involving intercropping of crops with trees on the same unit of land has been observed as a win-win strategy to meet the needs of wood products and food at the same time [21] [48]. The general idea behind the taungya system is to simultaneously plant agricultural crops and trees at the same area and let it grow until the tree canopy closes. It usually occurs 2 - 3 years after planting, but it is highly dependent on the types of crop that are being cultivated [49] [50]. Under this system, after the closure of crop cultivation, grass is often planted underneath the trees to create an opportunity for the local communities to have grazing for their cattle up until the end of the rotation. After the clear cut there are different ways to proceed depending on planting material, community wishes, and company directives if a company is managing the land.

The first alternative is to leave the grass cover and continue to have the grazing opportunity for the local communities and establish the new plantation through coppice. Meanwhile, the second alternative is usually to redo soil preparation and intercrop with cash crops or rice and plant new improved eucalyptus clones. Finally, the third alternative is to leave the grass and only do soil preparation in the tree lines and plant improved eucalyptus clones and let it grow into dimensions suitable for the local markets. In the Taungya system, farmers and their crop production are seen as the short-term goal of the agroforestry system, while the main aim and long term goal is to have productive tree plantations in the end [19] [51]. In this regard, taungya fits well into the concept of multiple land use by preventing the most serious consequences of shifting cultivation.

Additionally, under the Forest Stewardship Council (FSC) and The Forest Trust (TFT), local farmers around 18 villages in Luang Prabang province have learned better and responsible forestry practices [52]. Here trees that were once planted very densely together and left to grow are now planted in rows. This has been due to increasing awareness which has led growers to recognize the importance of thinning to open space and allow trees to grow, and pruning to promote clear boles. Farmers have also learned that protecting the organic matter promotes soil fertility and reduce erosion. Farmers have in addition significantly reduced burning and have begun allowing undergrowth vegetation [52].

\section{Conclusion}

In this study, we have analyzed forest degradation and loss patterns and explored the various drivers from the Laos perspective. We observed that in Laos as other tropical countries, majority of the population lives in rural areas with subsistence agriculture and forest resource harvesting as their major sources of livelihood. We also observed that the government of Laos is supporting afforestation and reforestation as well as stabilization of shifting cultivation. This is through the encouragement of commercial plantations of fast growing trees, including eucalypts such as to fill the gap caused by forest cover loss. Nevertheless appropriate forests resources monitoring, evaluation and management can only be achieved when an excellent information system and database are put in place 
or established by a country. The government should create the necessary incentives and policy instruments needed to encourage the combination of out-grower schemes and concessional plantations and to more effectively integrate timber plantations with traditional agricultural livelihoods. Though eucalyptus are important for being fast-growing sources of wood with a range of commercial uses, the cultivation of these tree species is also detrimental to the environment and survival of other plant species. Therefore, appropriate environmental impact assessment should be undertaken in order to limit the adverse ecological effects.

\section{References}

[1] Bwalya, S. (2013) Household Dependence on Forest Income in Rural Zambia. Zambia Social Sciences Journal, 2, 67-86.

[2] Ewane, B., Ewane, O. and Heon-Ho, L. (2015) Challenges to Sustainable Forest Management and Community Livelihoods Sustenance in Cameroon: Evidence from the Southern Bakundu Forest Reserve in Southwest Cameroon. Journal of Sustainable Development, 8, 226-239. https://doi.org/10.5539/jsd.v8n9p226

[3] Mukete, B., Sun, Y., Baninla, Y., et al. (2017) Perspectives of Remote Sensing and GIS Applications in Tropical Forest Management. American Journal of Agriculture and Forestry, 5, 33-39. https://doi.org/10.11648/j.ajaf.20170503.11

[4] Etongo, D. and Glover, K. (2012) Participatory Resource Mapping for Livelihood Values Derived from the Forest in Ekondo-Titi Subregion, Cameroon: A Gender Analysis. International Journal of Forestry Research, 2012, Article ID: 871068. https://doi.org/10.1155/2012/871068

[5] Nguyen, T., Truong, L., Bühler, D. and Grote, U. (2015) Rural Livelihoods and Environmental Resource Dependence in Cambodia. Ecological Economics, 120, 282-295. https://doi.org/10.1016/j.ecolecon.2015.11.001

[6] Ofoegbu, C., Chirwa, P., Francis, J., et al. (2017) Socio-Economic Factors Influencing Household Dependence on Forests and Its Implication for Forest-Based Climate Change Interventions. Southern Forests, 79, 109-116.

https://doi.org/10.2989/20702620.2016.1255420

[7] FAO (2014) Global Forest Resources Assessment and the State of the World's Forests. Rome.

[8] Etongo, D., Djenontin, I., Kanninen, M., et al. (2015) Land Tenure, Asset Heterogeneity and Deforestation in Southern Burkina Faso. Forest Policy and Economics, 61, 51-58. https://doi.org/10.1016/j.forpol.2015.08.006

[9] Mukete, B., Sun, Y., Ayonghe, S., Ojong, L., Itoe, C. and Tamungang, R. (2017) Adaptation of Women to Climate Variability in the Southern Slopes of the Rumpi hills of Cameroon. Agriculture, Forestry and Fisheries, 5, 272-279.

[10] Mukete, B. and Sun, Y. (2014) Assessing the Effectiveness of Urban Nature Reserves on Biodiversity Conservation. Applied Ecology and Environmental Sciences, 2, 130-134. https://doi.org/10.12691/aees-2-6-1

[11] Hansen, M., Potapov, V., Hancher, M., et al. (2013) High-Resolution Global Maps of 21st-Century Forest Cover Change. Science, 342, 850-853. https://doi.org/10.1126/science.1244693

[12] Weisse, M. and Goldman, L. (2017) Global Tree Cover Loss Rose 51 Percent in 2016. http://blog.globalforestwatch.org/data/global-tree-cover-loss-rose-51-percent-in-20 16.html 
[13] FAO (2005) Eucalyptus and Rural Development in Lao PDR-An NGO Perspective. http://www.fao.org/docrep/005/AC772E/ac772e0b.htm

[14] MONRE (2012) Ministry of Natural Resources and the Environment of LAO PDR. Lao Environment Outlook.

[15] Phimmachanh, S., Zhang, Y. and Mukete, B. (2015) Bamboo Resources Utilization: A Potential Source of Income to Support Rural Livelihoods. Applied Ecology and Environmental Sciences, 3, 176-183.

[16] Vongkhamheng, C., Zhou, J., Mukete, B. and Phimmachanh, S. (2016) Socioeconomic and Ecological Impact Analysis of Rubber Cultivation in Southeast Asia. Open Access Library Journal, 3, e2339. https://doi.org/10.4236/oalib.1102339

[17] Butler, R. (2006) Diversities of Image and Rainforest Biodiversity: A Place out of Time: Tropical Rainforests and the Perils They Face.

https://rainforests.mongabay.com/citation.htm

[18] WRI (2012) World Resources Institute. Global Forest Watch, 2012. http://www.globalforestwatch.org/country/LAO

[19] Chittana, P., Megan, L., Ostendorf, B. and Clarke, K. (2017) Forest Cover Changes in Lao Tropical Forests: Physical and Socio-Economic Factors are the Most Important Drivers. Land, 6, 1-14.

[20] CIA (2015) Central Intelligence Agency. The World Fact Book, 2015. https://www.cia.gov/library/publications/the-world-factbook/geos/la.html

[21] Edberg, S. (2015) Commercial Eucalyptus Plantations with Taungya System in Lao PDR: Analysis of Tree Root Biomass. Master of Science Thesis, Swedish University of Agricultural Sciences, Uppsala.

[22] Marjokorpi, A. (2016) Tree Plantations Improving Livelihoods in Laos. Forest Solutions Platform.

http://forestsolutions.panda.org/blog/tree-plantations-improving-livelihoods-in-lao s

[23] SLU (2008) Environmental Impact Assessment of Stora Ensos Commercial Plantations in Savannakhet and Saravanh Provinces, Lao PDR. Swedish University of Agricultural Sciences, Department of Soil and Environment, Uppsala.

[24] FAO (2010) Global Forest Resource Assessment: Key Findings. Food and the Agricultural Organization, Rome, $12 \mathrm{p}$.

[25] Shepherd, M., Bartle, J., Lee, D., et al. (2011) Eucalypts as a Biofuel Feedstock: Review. Biofuels, 2, 639-657. https://doi.org/10.4155/bfs.11.136

[26] Phimmavong, S., Ozarska, B., Midgley, S. and Keenan, R. (2009) Forest and Plantation Development in Laos: History, Development and Impact for Rural Communities. International Forestry Review, 11, 501-513. https://doi.org/10.1505/ifor.11.4.501

[27] Gledhill, D. (2008) The Names of Plants. 4th Edition, Cambridge University Press, Cambridge, 158. https://doi.org/10.1017/CBO9780511550898

[28] Palmer, J. (2014) Tasmania’s Giant Ash Trees May Be World's Tallest. http://www.bbc.com/earth/story/20141222-the-worlds-new-tallest-tree

[29] FAO (2001) Mean Annual Volume Increment of Selected Industrial Forest Plantation Species. Forest Plantation Thematic Papers. http://www.fao.org/docrep/004/AC121E/ac121e04.htm\#TopOfPage

[30] Nanko, H., Button, A. and Hillman, D. (2005) The World of Market Pulp. WOMP, Appleton, 107-109.

[31] Luzar, J. (2007) The Political Ecology of a "Forest Transition": Eucalyptus Forestry 
in the Southern Peruvian. Ethnobotany Research \& Applications, 5, 85-93. https://doi.org/10.17348/era.5.0.85-93

[32] Ball, J. (1995) Development of Eucalyptus Plantations-An Overview. Proceedings of the Regional Expert Consultation on Eucalyptus, Bangkok, 4-8 October 1993, Vol. 1, 15-25.

http://www.fao.org/forestry/25872-0c162e555bb41fe8fe9cf076acda4216d.pdf

[33] Bounphom, M. (2005) Eucalyptus in Lao PDR. http://www.fao.org/docrep/005/AC772E/ac772e0a.htm

[34] Manivong, V. and Cramb, R. (2008) Economics of Smallholder Rubber Expansion in Northern Laos. Agroforestry Systems, 74, 113-125. https://doi.org/10.1007/s10457-008-9136-3

[35] Rigg, D. (2006) Forests, Marketization, Livelihoods and the Poor in the Lao PDR. Land Degradation \& Development, 17, 123-133. https://doi.org/10.1002/ldr.719

[36] Vandergeest, P. (2003) Land to Some Tillers: Development Induced Displacement in Laos. International Social Science Journal, 55, 47-56. https://doi.org/10.1111/1468-2451.5501005

[37] Lang, C. (2006) Laos: ADB's Eucalyptus Plantations Increase Poverty. WRM's (World Rainforest Movement) Bulletin No. 103. http://wrm.org.uy/oldsite/bulletin/103/Laos.html

[38] Barney, K. (2008) China and the Production of Forestlands in Laos: A Political Ecology of Transnational Enclosure. In: Nevins, J. and Peluso, N.L., Eds., Taking Southeast Asia to Market. Commodities, Nature, and People in the Neoliberal Age, Cornell University Press, 280 p.

[39] Baird, G. and Shoemaker, B. (2007) Unsettling Experiences: Internal Resettlement and International Aid Agencies in Laos. Development and Change, 38, 865-888. https://doi.org/10.1111/j.1467-7660.2007.00437.x

[40] Chanthalath, X. (2017) Analysis of Factors Affecting Eucalyptus Plantation Quality and Management in Taoy District, Saravan Province, Laos. Master of Science Thesis, Beijing Forestry University, Beijing.

[41] FPC (2017) Eucalypt Plantations. Forest Products Commission, the Government of Western Australia. http://www.fpc.wa.gov.au/eucalypt-plantations

[42] Robertson, D. (2005) South Africa Water Project Clears Water-Guzzling Alien Plant Infestations.

https://web.archive.org/web/20090115005010/http://www.voanews.com/english/arc hive/2005-03/2005-03-22-voa19.cfm

[43] FPC (2017) The Benefits of Tree Farming. Forest Products Commission, the Government of Western Australia. http://www.fpc.wa.gov.au/farm-forestry

[44] FAO (1991) What Can We Learn from the Great Eucalyptus Debate? In: Raintree, J.B., Ed., Socioeconomic Attributes of Trees and Tree Planting Practices, Community Forestry Note 9, FAO, Rome. http://www.fao.org/docrep/005/ac777e/ac777e08.htm\#TopOfPage

[45] Cheng, F. and Cheng, Z. (2015) Research Progress on the Use of Plant Allelopathy in Agriculture and the Physiological and Ecological Mechanisms of Allelopathy. Frontiers in Plant Sciences, 6, 1020. https://doi.org/10.3389/fpls.2015.01020

[46] Foley, S. (2009) Laos-Planting for the Future: Environmental and Social Codes of Practice for Industrial Tree Plantations-An Overview. Volume II-Annexes. http://www.laolandissues.org/wp-content/uploads/2011/12/Foley-Planting-for-Futu re-Volume-II-Annexes-June-2009.pdf 
[47] Nanthavong, K., Khambanseuang, C. and Castella, J. (2011) The Economics of Industrial Trees Plantations in Lao PDR: Incentives or Constraints to Land Conversion. The Lao Journal of Agriculture and Forestry, 23, 50-60.

[48] Jordan, J., Gajaseni, J. and Watanabe, H. (1992) Taungya: Forest Plantations with Agriculture in Southeast Asia. CAB International, Wallingford.

[49] Kalame, F., Aidoo, R., Nkem, J., Ajayie, O., Kanninen, M., Luukkanen, O. and Idinoba, M. (2011) Modified Taungya System in Ghana: A Win-Win Practice for Forestry and Adaptation to Climate Change? Environmental Science \& Policy, 14, 519-530. https://doi.org/10.1016/j.envsci.2011.03.011

[50] Ros-Tonen, F., Insaidoo, T. and Acheampong, E. (2013) Promising Start, Bleak Outlook: The Role of Ghana's Modified Taungya System as a Social Safeguard in Timber Legality Processes. Forest Policy and Economics, 32, 57-67.

https://doi.org/10.1016/j.forpol.2012.11.011

[51] Chamshama, S., Monela, C., Sekiete, A. and Persson, A. (1992) Suitability of the Taungya System at North Kilimanjaro Forest Plantation, Tanzania. Agroforestry Systems, 17, 1-11. https://doi.org/10.1007/BF00122924

[52] Bröcker, K. (2015) Five Years in Laos.

http://www.tft-earth.org/stories/blog/five-years-in-laos/ 